\title{
Challenges in conducting and publishing research on the Middle East and Africa in leading journals
}

Article

Accepted Version

Lages, C., Pfajfar, G. and Shoham, A. (2015) Challenges in conducting and publishing research on the Middle East and Africa in leading journals. International Marketing Review, 32 (1). pp. 52-77. ISSN 0265-1335 doi:

https://doi.org/10.1108/IMR-12-2014-0374 Available at https://centaur.reading.ac.uk/38698/

It is advisable to refer to the publisher's version if you intend to cite from the work. See Guidance on citing.

To link to this article DOI: http://dx.doi.org/10.1108/IMR-12-2014-0374

Publisher: Emerald

All outputs in CentAUR are protected by Intellectual Property Rights law, including copyright law. Copyright and IPR is retained by the creators or other copyright holders. Terms and conditions for use of this material are defined in the End User Agreement.

www.reading.ac.uk/centaur 
Central Archive at the University of Reading

Reading's research outputs online 


\section{Challenges in conducting and publishing research on the Middle East and Africa in leading journals}

Cristiana R. Lages, Gregor Pfajfar and Aviv Shoham

\section{Introduction}

International marketing research in emerging markets (EMs hereafter) is scarce. The relatively few papers drawing on data from EMs published in influential marketing journals include Batislam et al. (2007), Erdem et al. (2006) and Grier and Deshpandé (2001). This situation is in contrast to what occurs in developed markets where much international marketing research has been conducted. Some scholars recognize the existence of this gap in the literature by highlighting that reviews of research conducted in the Middle East (ME hereafter) and Africa in any marketing journals have been few and fragmented (Onyancha, 2011). Yet, no study has identified the resultant potential problems in terms of international marketing theory development and practice. In particular, a potential problem is that existing theories are likely to hold differently in different contexts. For instance, Story et al. (2014) found that access to financial resources is more important in Ghana compared to the UK as it enhances the relationship between product innovativeness and new product performance in Ghana but not in the UK. Moreover, while UK firms benefit from firm-level product innovativeness in more dynamic environments, product innovativeness is less beneficial for Ghanaian firms when market dynamism is high.

Such differences contribute not only to theory development, but also to managerial and governmental practice providing a strong case for conducting research in EMs. For instance, Story et al. (2014) recommend that Ghanaian policy makers should enhance access to financial resources to guarantee firms' product innovation success and that managers in Ghana should be aware of dynamism increases and focus on entering less-established rather 
than highly dynamic and competitive markets. Thus, the scarcity of research in the ME and Africa is important for two reasons. First, given the diversity and contrasting nature in both formal and informal institutions across markets (North, 1990), scholars are missing an opportunity to advance international marketing theory by carrying out most research in developed markets and overlooking EMs. The lack of research in Africa and the ME in particular may translate into new constructs not being developed, conventional thinking not being questioned (cf. Burgess and Steenkamp, 2006) and potential moderators of theoretical relationships uncovered in existing research not being tested (cf. Walters and Samiee, 2003). Hence, in terms of international marketing theory development, some theories developed and tested in advanced economies might need tweaking. Second, from a practical standpoint, such tweaking might carry new managerial and public policy implications as research recommendations based on the extant literature on developed markets may be invalid or may need to be modified for EMs. In other words, academics and managers require different theories and tools for EMs. In short, this study contends that a gap exists in the marketing literature and that indiscriminately borrowing theories and recommendations based on studies in developed markets might be a misguided approach. Hence, given the scant research conducted in the ME and Africa in the marketing field and its implications for theory and practice mentioned above, this crucial gap in knowledge needs to be urgently understood and addressed.

As a first step, the main goal of this study is to examine the reasons why marketing research in these regions is scant and to identify the inherent challenges of conducting and publishing research on these regions. Accordingly, the research question is: What are the reasons for the paucity of studies in the marketing field on the ME and Africa regions published in high-quality international journals? Once these reasons are investigated, we can then provide guidelines aimed at enhancing the understanding of marketing models. In order 
to achieve this goal and address the research question, the 23 most influential journals of marketing, international business, and advertising were included.

The contributions of this study are threefold. First, it provides evidence of the lack of marketing studies in the ME and Africa regions. Second, it investigates the reasons and inherent challenges of conducting and publishing research on these regions. Third, and most importantly, it suggests potential solutions for these challenges in order to guarantee the advancement of international marketing theory and practice.

The structure of the paper is as follows. The Background section highlights the importance of EMs in general and the ME and Africa regions in particular. The two regions differ and the nature of these differences will become evident below. This is followed by the Methodology section, which describes the systematic literature review and the Delphi study conducted (cf. Fastoso and Whitelock, 2011). In the Findings and discussion section, we focus on the challenges of conducting research in these regions and publishing it in highquality international journals. The Conclusions section discusses implications for future research and managerial practice.

\section{Background}

\subsection{Emerging markets}

Are EMs different from other markets? Should they attract market-specific scholarly attention? EMs tend to exhibit low income per capita, but simultaneously "a rapid pace of economic development, government policies favouring economic liberalization, and a free market economy" (Hitt et al., 2005, p. 354). Despite EMs being the focus of sustained research in the last two decades (Kearney, 2012), marketing science and practice could benefit from further research in these markets (Burgess and Steenkamp, 2006). Theoretically, these markets represent a testing ground for existing theories and conceptual models due to 
the enormous changes they have experienced (Akbar and Samii, 2005). They also represent an opportunity to develop new constructs that were overlooked in earlier research, while at the same time challenge conventional thinking (Burgess and Steenkamp, 2006). Additionally, given their diversity on issues such as culture, which have an important business impact, EMs provide fruitful contexts in which to test potential moderators of theoretical relationships uncovered in research on developed markets (Walters and Samiee, 2003). Furthermore, insights on these business environments and marketing systems can contribute to the body of knowledge in international marketing (Schuh, 2010).

From the perspectives of managers and public policy makers, EMs are not only growth engines of the global economy (Pillania, 2009), but they comprise a vast part of the world. They include 4.8 billion people in 156 nations and continue to grow faster than developed countries (Kearney, 2012), which makes them a large potential market for internationalizing companies (Akbar and Samii, 2005). Accordingly, research on these markets should expand to match their growth and development. This investigation should contribute to a better understanding of the reasons for the regions' lack of research attention, which is a required first step in encouraging scholars to study and report on marketing phenomena, be they similar or different from developed markets.

\subsection{The ME and Africa regions}

In this section, we focus on the ME and Africa regions, highlight the importance of these regions, and provide a background for both regions. The importance of the ME and Africa regions has been recognized by scholars with recent calls for research on EMs (e.g. Fastoso and Whitelock, 2010, 2011; Okazaki and Mueller, 2007). Moreover, "despite being in the frontlines of popular media and in the back seat of the academic research" (Demirbag et al., 2011, p. 412) and having been portrayed by the sensationalistic media as politically unstable 
and potentially violent, the ME and Africa regions remain attractive for foreign investors and multinational enterprises (Demirbag et al., 2011; Mellahi et al., 2011).

The ME is a socio-cultural and political region without specific borders (Mellahi et al., 2011), characterized by a "diversity of ethnicities, languages, and religions", as well as heterogeneous economic and political structures (Mellahi et al., 2011, p. 406). Specifically, the ME's "social, economic and political terrain is littered with half-formulated or unimplemented ideas, in stark contrast with the reality of often small populations, remarkably abundant natural resources, stagnant labour markets, traditional antipathies and newer enmities, set against the global backdrop of geopolitical tensions originating in the Middle East and now shaping our world" (Ruscoe, 2008, p. 6). Notwithstanding the ME's economic and political importance (Godley and Shechter, 2008), marketing (and international business) research in this region has been limited to specific countries, such as Saudi Arabia (Luqmani et al., 1989; Razzouk and Al-Khatib, 1993; Melewar et al., 2000), Kuwait, UAE, Lebanon, and Egypt (Melewar et al., 2000). Only recently, has a wider range of countries been investigated (Jordan, Algeria, Bahrain, Iran, Kuwait, Oman, Qatar, Syria, Tunisia, and Turkey; e.g. Demirbag et al., 2011). However, the ME is still characterized by a dearth of research (Mellahi et al., 2011; Godley and Shechter, 2008). Accordingly, there is a need for academic research, in which scholars should be open to and foster interaction with the economies, societies, and international partners in these countries (Ruscoe, 2008).

Africa is also characterized by diverse economic, historical, and socio-political subregions (Kamoche, 2011). It comprises 59 countries (United Nations, 2012); boasts the world's highest GDP growth rate (Kamoche, 2011); and its billion-plus inhabitants exceed Europe and the USA's together and speak over 2000 languages. Indeed, some argue that Africa is the land of the future (Adesida and Kururi-Sebina, 2011). Despite being a "great promise as the last economic and industrial frontier" (Kamoche, 2011, p. 1), similar to the 
ME, Africa is an under-researched region (Okazaki and Mueller, 2007; Al-Olayan and Karande, 2000).

Research in the ME and Africa published in the most influential marketing journals has addressed issues such as branding and product evaluations (Erdem et al., 2006; Essoussi and Merunka, 2007; Lee et al., 2010), segmentation (Al-Khatib et al., 2005 ; Souiden, 2002), advertising (Oyedele et al., 2009; Speck and Roy, 2008), channels (Tesfom et al., 2004; LeeKelley et al., 2004), consumer behaviour (Grier and Deshpandé, 2001; Batislam et al., 2007; Steenkamp and Burgess, 2002), and relationship marketing (Abdul-Muhmin, 2005; Babakus et al., 2003). Additionally, international marketing research has addressed country-of-origin effects (Ahmed and d'Astous, 2008), cultural differences (Kalliny, 2010), and entry modes (Gilmore et al., 2003). Nevertheless, very few papers on the ME and Africa have been published in the top marketing journals (e.g. Journal of Marketing, Journal of Marketing Research, Journal of Consumer Research), international business journals (e.g. Journal of International Marketing, International Marketing Review) or advertising journals (e.g. Journal of Advertising), and most studies on these regions have been based on research conducted in developed countries (cf. Burgess and Steenkamp, 2006). Thus, we concur with others, who acknowledge the importance of the ME and Africa regions and the scarcity of research in both regions, which have led to a special issue on the ME (Journal of World Business, Vol. 46, No. 4) and another on Africa (Journal of World Business, Vol. 46, No. 1). Our study follows the tradition of these special issues and continues the journey towards high-quality international research on the two regions. 


\section{Methodology}

In line with recent research (e.g. Fastoso and Whitelock, 2011; Lahiri, 2011), we conducted a systematic review of the literature. Rigorous systematic reviews "summarize in an explicit way what is known and not known about a specific practice-related question" and constitute "a replicable, scientific, and transparent approach" (Briner et al., 2009, p. 19, 25). This study's research question guided the identification of journals and time frames, selection of keywords in an online search of databases, the data to be extracted for each study, and scrutiny of the papers in those journals that are relevant for the study (see Briner et al., 2009; Fastoso and Whitelock, 2011).

Marketing papers are most likely to be published in marketing, international business, and advertising journals (Fastoso and Whitelock, 2011). Based on previous reviews on the most influential journals in marketing (Touzani and Moussa, 2010; Leonidou et al., 2010; Hult et al., 2009), international business (DuBois and Reeb, 2000), and advertising (Henthorne et al., 1998; Royne Stafford, 2005), 23 journals were identified (Table I).

\section{[Insert Table I about here]}

The time frame of the study was defined between 2001 and 2011 (see Fastoso and Whitelock, 2011). Keywords included in the online search of available databases (including ProQuest and EBSCO) were marketing, advertising, brand, branding, price, pricing, distribution (Fastoso and Whitelock, 2011), marketing channels, marketing mix, standardization, adaptation, service marketing, and services marketing. Additionally, keywords included the names of the regions, as well as the names of all the countries in these regions as defined by the World Bank (2011) and/or United Nations (2012). In total, 53 keywords were used for the ME and 95 for Africa. This search resulted in 301 articles. In line with Fastoso and Whitelock (2011), only papers based on primary or secondary data collected 
from a local source (rather than international organizations, which are not affected by the specificities of the regions) were included. Additionally, given that access to advertisements is easier than access to primary or secondary data from a local source, papers based on content analysis of advertisements were also excluded. The final sample included 125 papers.

Next, a Delphi study was conducted. The advantage of a Delphi study is that it "provides for an interactive communication structure between researcher(s) and 'experts in a field' in order to develop themes, directions, or predictions about a topic" (Griffith et al., 2008, p. 1222). Accordingly, the participants were the authors of the 125 papers. As some authors published multiple papers, we contacted 60 first authors by email. When the contact details of the first author were not available, we contacted another author. The personalized email explained the aim of the study, the reason why the authors were contacted, and specified their article(s). Authors were asked four questions:

1) What are the major challenges involved in conducting research in the ME and/or Africa (please name and describe them in order of decreasing importance)?

2) What are the major challenges involved in publishing such research in high-quality international journals (please name and describe them in order of decreasing importance)?

3) What would you recommend to future researchers who want to gather data in the ME and/or Africa and later publish those results in high-quality international journals?

4) What are the most common reviewers' comments specifically relating to the country of your study?

Of the 60 scholars contacted, 42 responded. The $70 \%$ response rate is slightly lower than Fastoso and Whitelock's (2011) but in line with Griffith et al.'s (2008) study. Following established guidelines for qualitative research (Hirschman, 1986), the analysis was multiperiod and multi-level. It followed the notions of "integrity" and "systematic" (Cohen, 1999) by being prolonged and triangulated, involving researchers' retrospection (Wallendorf and 
Belk, 1989). The first level of analysis involved separate analyses of the 42 responses by two of the co-authors in order to identify emerging themes and their inter-relationships. The second stage involved continuous and iterative interactions between these two co-authors, culminating in preliminary models for the ME and Africa. The third stage involved a reading of the original "data" (verbatim responses of participant authors) by the third co-author, who then analysed the data and compared the analysis results to the two preliminary models.

A continuous discussion among the co-authors followed an "observations $\rightarrow$ theme formation $\rightarrow$ new observations $\rightarrow$ revised themes" process. The co-authors strove to avoid premature conclusions and made an effort to account for the fact that the task was a full understanding of the phenomenon, its building blocks, and their inter-relationships. The participant authors were contacted a second time and given the opportunity to provide additional comments on the results. Based on their comments, discussions among co-authors were held to arrive at consensus regarding several changes to the two models.

\section{Findings and discussion}

The first and second questions to our panel of experts focused on the challenges involved in conducting research in the ME and/or Africa and in publishing such research in high-quality international journals (see Tables II and III). Next, we describe the challenges faced in both regions, challenges arising in each region, and challenges in countries that present particular characteristics.

\section{[Insert Tables II and III about here]}

\subsection{Challenges faced in conducting research in the ME and Africa}

From the answers to the first question, three themes emerged: data-related issues, region diversity, and the lack of priority given to research. With regard to data, key issues included 
low participation rates, respondents' suitability, quality of primary and secondary data, and the lack of secondary data. With regard to primary data collection, one respondent said: There may be problems with data collection in the rural areas [in Africa]. Depending on your sample, there may be a lack of reading and writing skills. In turn, the challenges might be different in terms of data collection in an organizational context, as a respondent noted: For organizational research, very few organizations [are] willing to allow research [and it is] difficult to obtain permission. This may be either formal policy or when it is sometimes allowed, long delays for feedback from the organizations [exist]. Skill shortages in most companies cause heavy workloads, and it may be difficult or impossible to get the attention of a chosen respondent within an organization. This finding for organizational research is aligned with Fastoso and Whitelock (2011, p. 440), who highlighted "the lack of company support for research" in EMs. The findings also resonate with Kemp's (2010) claims that conducting fieldwork in these countries is extremely problematic. With regard to secondary data availability, a respondent said: Company data are hard to find, [there are] poor disclosure rules, many SMEs that do not report, lack of proper inflation data for time series, multiple exchange rates for cross-country work. Overall, there is a perception that a major challenge is the data availability and quality of data in comparison to data available in advanced economies and some other developing countries. Indeed, reliable data are scarcely available and when available there are limited opportunities to cross-check certain facts, as noted by another respondent. This finding, in line with research on EMs (Fastoso and Whitelock, 2011; Craig and Douglas, 2005), emphasizes the lack of secondary data availability and reliability in the ME and Africa.

Diversity of the regions was a second emerging theme. Our experts considered this diversity to be a major challenge given its implications in terms of generalization of results. In particular, a respondent argued that the diversity of the region makes it challenging to 
generalize. Good research often involves collecting data from multiple countries that are quite diverse from each other. This high diversity of markets requires scholars to conduct comparative research on EMs, which is very costly (Sakarya et al., 2007).

The third theme is the fact that research is regarded as unimportant by the academic community. An expert attributed it partly to the lack of incentives as well as support to researchers in MENA (Middle East and North Africa). Another expert noted: as far as research in Africa is concerned by the local academics, the problem is that universities in Africa focus on teaching and there are many consulting opportunities. Research is a low priority. Others agreed and noted the little time for research and limited budgets to collect significant and representative samples, as well as the limited resources [regarding] budgets for research, behavioural labs, established and available datasets about firms, very limited post-docs. Another scholar summarized the situation by arguing that many African universities are chronically under-resourced, and work under very difficult conditions. In sum, these regions have universities that focus mostly on teaching and consultancy and subsequently do not allocate resources to research (see Kamoche, 2011).

\subsection{Challenges faced in publishing research in the ME and Africa}

Four themes emerged from the answers to the second question, namely data validity and reliability, generalizability of the results, editors' and reviewers' low interest in the regions, and their limited knowledge about the regions. With regard to data validity and reliability, a major challenge is establishing the validity of the constructs utilized in the study. According to another expert, since most of the measures have been developed in the western world, several of these measures do not make sense to respondents even if translation is conducted appropriately. For example [...] if you translate love and like into Arabic then they both translate into the same word. This comment highlighted the fact that testing the validity of 
concepts from western economies in EMs is not adequate for publishing in highly ranked journals (Fastoso and Whitelock, 2011). Another expert provided the solution for the validity problem, namely to triangulate results with multiple data sources. In terms of reliability, an expert noted that reviewers will typically question the quality of the data, including its reliability, validity, completeness, representativeness, and so forth.

Generalizability of findings was also seen as a challenge. As an expert noted, the external validity and generalizability concerns make cross-country studies a necessity to be able to publish in top journals. Top journal reviewers and editors are concerned with generalizability of results, which is addressed by cross-country studies.

Strong views were expressed about editors' and reviewers' low interest in the region. An expert quoted a comment that he received on a paper: "Why is this problem of your country so interesting for our readers?". This comment was received from a journal that specializes in 'development' and the expert assumed that the journal's audience would be interested in a ME country. Another expert received the following feedback "of no interest for the audience", which he argued to be the US audience. While an expert acknowledged that thanks in part to the emergence of large developing countries like India or China, there is an increased interest in developing countries and it is easier to publish research on the Middle East or other developing countries he recognized that there are still too many preconceptions and misunderstandings. One expert agreed and suggested that editors [are] more interested in methodology than novel findings from new contexts and there is a lack of interest in studies based in these countries (in spite of lip-service paid to international studies).

Editors and reviewers also exhibit limited knowledge about the regions. An expert noted that sometimes reviewers' knowledge of the region is limited. Another expert regarded this lack of knowledge as an opportunity. He suggested that authors should use the lack of knowledge about the region as a selling point of the paper, focus on topics that are not 
prevalent in other regions and sell the idea of firms in the region as a laboratory, provide background information on the region and its firms to solve preconceptions and lack of knowledge of reviewers. Another expert discussed situations in which editors' and reviewers' positions were mixed: either misperceptions due to lack of knowledge, or "this is great that you [the author] are using a different context". Finally, the limited knowledge about the regions also carries through to being unfamiliar with scholars in these regions: international journals' editors and editorial board members lack familiarity with researchers from non-US countries.

\subsection{Challenges faced in conducting research in the $M E$}

Three ME-specific themes emerged - general lack of trust in and suspicion about surveys, country-specific research design challenges, and weak university-company links. With regard to a general lack of trust, an expert explained that in some places you even run into suspicion of the survey [as an instrument], because they [survey respondents] are not familiar with the process. He elaborated that in some cases you have to get government permission to conduct research, which makes the data even more suspect. Moreover, it is often even difficult to figure out how to contact businesspeople to interview, because so much has to be done through personal contact, which compromises the randomness required.

With regard to country-specific research design challenges, the experts discussed the difficulties to approach women as respondents and the problem that door-to-door data collection is prohibited in some countries like Qatar. Based on experts' observations, key issues are generally related to research design: One of the main problems is that some countries in the Middle East (e.g. Bahrain, Oman, etc.) are very small (in terms of population size and market potential) and, therefore, they are not considered as of big interest to academicians and industrial experts. The same expert added: as a matter of fact, the bulk of 
the research in the region is done on Saudi Arabia. Instability and violence in some countries were also mentioned as research barriers.

A weak university-company link was mentioned by experts in relation to no/low levels of research funding by companies. As an expert noted industry-university collaboration is a must [...], especially for the consumer studies, as the consumers are easier to convince into participation with small gifts such as small home appliances. To summarize, funding is a must to conduct research in the Middle East.

\subsection{Challenges faced in publishing research on the $M E$}

Four ME-specific themes emerged: a limited number of region studies to draw from, limited exposure to international scholars' work and lack of competent collaborators, a need for highquality writing, and difficulty in becoming members of "in-clubs" in the West. With regard to the limited number of studies in the region to draw from as a literature base on which to rest one's study the experts recognized this as a diminishing problem. This literature is only now emerging at a faster pace and greater volume than before. This is a function [the expert believes] of increasing emphasis placed on scholarly research at universities in the emerging markets, and by extension in Middle Eastern countries, and the rising interest by emerging market firms in scholarly research that they increasingly believe will actually help them grasp problems and understand opportunities more effectively.

The second issue relates to a limited exposure to international researchers' work. As an expert explained, it is common in the region to travel and present in research seminars and $[\ldots]$ there are much less relevant outlets $[\ldots]$, which means that your work is less likely to be enjoying high-quality feedback and potential reviewers will not get a sense of your work. Given the poor/unconventional training of local researchers, a lack of competent collaborators was highlighted as an additional challenge. 
When speaking about reviewers, one expert noted: In my experience as a reviewer and editor, the \#1 problem is writing quality. People who are writing in a second language simply MUST run their work by a good technical editor BEFORE they send it to the journal, or they risk having it rejected at the editor's desk, with no opportunity for resubmission. Notably, many universities have become aware of this problem and an English proficiency exam is required before taking a position at the university in some countries.

Fourth, experts recognized the difficulty of becoming members of clubs in the West. As the establishment is based in developed economies..., many research [papers] on countries that are not in the primary interest of Western establishment are easily rejected, hence many capable native researchers rather pursue questions that are relevant to Western concerns. Methodology is another facet of the issues: problems these countries are facing sometimes may be structurally different, and therefore may require novel approaches. Yet, researchers opt for "standard" approaches, as they are more likely to obtain favourable referee reports. This, in turn, reduces research on non-West countries to exercises on a known theme. In sum, once you are a member of "clubs" in the West, one can more easily publish in high-quality journals. However, this might be changing: data from the $M E$ is viewed as exotic, interesting, and attractive for many journals today as they seek diversity.

\subsection{Challenges faced in conducting research in Africa}

Several Africa-specific themes emerged: costs of gathering data and the small number of $\mathrm{PhD}$ graduates as well as inexistence of incentives for international publications. With regard to costs of gathering data, the experts mentioned temporal issues arising from delayed communication with partners. Extensive training of individuals conducting surveys in the native language and verification of this training were also discussed. Furthermore, $U K / U S$ models cannot be assumed to apply in Africa e.g. competition, price efficiency, [...] and most 
of the scales do not work with non-student population. Since most of the scales do not work, quantitative research is generally pointless with non-students. Individuals collecting data require careful definition and explanation of survey concepts. Finally, costs of gathering data may increase due to a great deal of government intervention (many industries are heavily subsidized), taking into account high levels of corruption and poor governance. Corruption can affect data collection in a number of ways from (1) having to pay senior officials for data access to (2) local field resources that were pledged to support the project (money, equipment, people, etc.) being "redirected" to other areas/people and therefore no longer accessible by the research team even though they were pledged to support the project.

One expert argued that there is a difference in challenges faced in conducting research in Africa both as an outsider looking in and as an insider. From the perspective of nonAfricans, international researchers may be unaware of issues and aspects that are country and/or region specific - and may therefore miss aspects during the conceptual development of the study, such as cultural issues or intervening variables that need to be incorporated in the research design [...] e.g. vast distances, under-developed areas, power failures, extreme poverty, large areas without internet or cellular networks may be issues when the scope of the study is to be inclusive at all levels. For an Africa insider, the most alarming issue is the majority of university scholars without PhDs: many of them are enrolled for either a Master's or Doctoral degree; therefore, the teachers are still learners and have divided attention. Furthermore, there are no incentives for publications at high international level: incentives for research excellence do not distinguish between international high-quality journal publications and lower-quality locally accredited journals. The final challenge is the political instability in certain regions, for instance of a country, and consequently the lack of research conducted in these regions. 


\subsection{Challenges faced in publishing research on Africa}

The survey revealed two major challenges: limited publication outlets and lack of Africaapplicable theory. An expert argued that there are few highly reputed international journals that accept qualitative research, even case method based research [...] and international journals still prefer standard articles that use well-proven statistical methods, while deviations tend to reduce the quality of the article in the eyes of reviewers. This issue led him to the second challenge: as much work is case-based and/or not theoretical, it is hard to find theoretical hooks. Another expert added that publication in high-quality journals is challenging, because a majority of these journals are targeted to American and European audience[s] and advised: You can increase the potential of publication if the background and findings from the study is put into US and European context [...], but do not use brute force to fit existing theory on the African context. Also, the author should look out for special issues on emerging markets. Thus, experts agreed it is best for researchers to frame and reframe their work to join a conversation already started in developed countries, by (1) using the African context as a background for the research (do not position the paper as a study of $X$ in an African country), and (2) being clear about the contribution (claiming that X has not been studied in [an] African country $Y$ is not enough).

\subsection{The outliers: South Africa, Israel, and Turkey}

Notably, these three countries emerging as outliers was not anticipated a priori. Speculatively, many scholars originally from these countries have graduated from US doctoral programs and some have not returned to their original native countries. As noted by a respondent, there appears to be a bias in many of the best marketing journals towards research about developed countries, most notably the US and Europe. Even when studies are based on data from other countries, there appears to be a bias towards publishing research 
based on the approaches prevalent in the US, that were taught to students during their $\mathrm{PhD}$ programs. If these biases exist, scholars from South Africa, Israel, and Turkey, who are thoroughly trained and, in some cases, have adopted the US as home, would be evident in a larger number of publications on these countries. While this explanation is speculative and requires additional research, several examples should illustrate the intuitively appealing nature of this explanation. Thus, we find several publications about Turkey by scholars such as Tamer S. Cavusgil, Erdener Kaynak, Ayşegül Özsomer, and Atilla Yaprak. Likewise, scholars such as Amir Grinstein, Chezy Ofir, Israel D. Nebenzahl, Aviv Shoham, and Eugene D. Jaffe have published papers about Israel, and scholars like Kamel Mellahi and Jenifer Piesse, about South Africa.

\subsubsection{Challenges of conducting and publishing research in South Africa. Our experts} highlighted the fact that [not] all comments [made beforehand for Africa] relate to South Africa (see Figure 1). With regard to secondary data, the expert noted that [...] data there is quite good. It [South Africa] has an excellent stock exchange with $1^{\text {st }}$ world systems and complies with international standards of accounting, audit and disclosure. Another challenge with regard to primary data collection was that for qualitative research: there is a need to spend time in the field [...] to understand the dynamics of the country. This is corroborated by another expert who argued that you need to link in with someone who knows the culture. Finally, an expert explained that in the case of South Africa, there are clusters of South African based scholars who form relatively closed camps, and are unreceptive to new work. This highlights the lack of potential research collaborations that characterize emerging economies (Fastoso and Whitelock, 2011). The advantage of South Africa is that there should be no problem, certainly in the large cities with regard to internet connectivity and poor infrastructure. Another expert added that indeed reviewers are generally intrigued by the 
South African context and find the "context" very interesting.

With regard to publishing, an expert pointed out that with South African data that you want to have published, [...] you have to be better than excellent to get your results published in good quality journals. This comment corroborates the finding about a negative bias towards African-based research.

[Insert Figure 1 about here]

4.7.2. Challenges of conducting and publishing research in Israel and Turkey. Our panel highlighted the fact that [...] all comments [made beforehand for ME] do not relate to Israel and Turkey (see Figure 2). In particular, it depends on what the research topic is; e.g. for banking and hospitality service sectors there is no unique difficulty that is different compared to western locations - you have to have good connections for data collection, you must be very careful in study design since translation of data collection instruments will be necessary. In fact, some experts claimed that ME research should be easier: in terms of respondent rate because the managers have not been approached and bombarded with as many surveys as the managers in the US. As an expert argued, survey response rates for managerial questions are very low in the US, as low as 8-12\%, whereas in Turkey [it] has been much higher, as long as the research question is of interest to managers and care is taken to increase response rates (e.g. delivering an executive report of research results, face-to-face filling of surveys instead of mail surveys).

While the experts argued that some challenges are similar across all world regions: the willingness of people to take part in the survey (low response rate), perceived anonymity, social desirability, cost of data collection, other challenges are unique. Specific to Israel is its small size (around 8 million), with major religion and culture differences from European or US individuals. Thus, results obtained from Israeli surveys can be used as a business case 
unless they support theoretical models. On the other hand, a major challenge in conducting research in Turkey is the replication of previous findings in literature in a Turkish context and the lack of prior knowledge and education on how to conduct a quality research that will be accepted by major publication outlets. An expert elaborated: the professors who have publications in leading journals are only confined to top 5-6 universities (and most of them with PhD degrees from US/European Universities), while the PhD students or lower rank instructors in the remaining 150 universities are deprived from such guidance. To give some

figures, I guess there are only 15-20 marketing professors of any rank [...] who have published in a journal covered by ISI. This being the case, most young scholars do not receive guidance on: a) what has already been said in theory and what has not, b) what literature gaps are present and/or how these literature gaps can be addressed, c) how can one contribute to the theory while satisfying the expectations of the leading journals, and $d$ ) how a rigorous academic paper is developed.

Nevertheless, some experts saw opportunities to conduct research in these two countries. They recognized that it is easier to collect data in Israel and in particular from consumers (compared to other countries in the ME region). Additionally, the Middle East and Israel in particular are great places for cross-culture research. Finally, Israel is well suited to conduct research focusing on new ventures and the high-tech industry.

$$
\text { [Insert Figure } 2 \text { about here] }
$$

\section{Conclusions}

To reiterate, our study confirms arguments that many factors could explain why Africa has been under-researched (cf. Okazaki and Mueller, 2007; Al-Olayan and Karande, 2000) and goes beyond these studies by systematically mapping the most contemporary research issues in the region. These issues comprise the lack of resources and commitment to research at the 
institutional and governmental levels, the lack of skills of academic staff to conduct highquality research, institutions' focus on teaching and inherent heavy teaching loads, inadequate infrastructure (cf. Sawyerr, 2004; Kamoche, 2011), and the tendency to reduce the African continent to the study of South Africa (cf. Okazaki and Mueller, 2007).

Likewise, research about the ME has also provided explanations for the region being under-researched (cf. Kemp, 2010; Ruscoe, 2008). These explanations include field-research constraints in terms of obtaining research clearance and limited sources available for consultation while in the field (Brand, 2007), different understanding of the "theory" by local scholars and consequent criticism in the West (Bilgin, 2006), low information literacy (Fahmy and Rifaat, 2010), and education quality (Heyneman, 1997).

Both regions are characterized by problems in access to fieldwork due to three barriers (cf. Kemp, 2010): (1) a great deal of time is spent in contacting gatekeepers; (2) once a contact is established, the negotiation to get access to respondents is prohibitively long; and (3) employees are often suspicious of being "under the microscope", especially a foreigner's.

Our study has moved beyond these simplistic and, at times, speculative assertions by finding support to some unsubstantiated arguments raised previously. For instance, the issue of access to fieldwork is captured in our study by the challenge named "access to data" in both regions. The barriers have also been corroborated in our study and are included under challenges with "data collection (time consuming)" and "business environment" in Africa (Table III), and "general lack of trust", "lack of institutionalization" and "a need for personal contact" in the ME (Table II). Moreover, comparative research of EMs is very costly because of high diversity of markets or because previous research on those markets is lacking (Sakarya et al., 2007). Our experts corroborated this argument by acknowledging the diversity of Africa (Table III) and the differences between cultures in the ME (Table II). In addition, experts also highlighted the issue of the limited number of studies in the ME to 
draw from (Table II) and the lack of theory applicable to an African business context (Table III).

While some past research assertions have been supported by our study, our findings contradict others, such as the argument that academic freedom is a key concern for scholars studying the ME. Such a concern was attributed to cases of authoritarian regimes preventing academics from conducting research, dismissing them from teaching positions, and at times imprisoning them because of their work (Brand, 2007). In this study, academic freedom did not emerge as an important issue among our experts.

Furthermore, in addition to contradicting existing research assertions, our study provides new insightful results. Noteworthy is the focus on editors' and reviewers' low interest in the regions. Our study concludes that this low interest is mostly anchored in preconceptions of the region, namely the quality of research conducted and the possibility of generalizing the results to other countries and regions. This low interest is fuelled by a lack of editors' and reviewers' knowledge about these regions (Tables II and III). Moreover, South Africa, Israel, and Turkey emerged as outliers, where research challenges are not as evident as in other countries in the region, potentially explained by the number of researchers with western training or working in a developed country, where the identified research problems do not exist. In addition, these countries (particularly South Africa) are economically more developed than other countries in the region. This study offers some additional insights and solutions to face the challenges of conducting and publishing research in both regions (see Table IV).

\section{[Insert Table IV about here]}

To this point, we have sought ways to encourage scholars from the investigated regions to publish in high-quality international marketing journals. However, they might not 
wish to publish in these journals for various reasons. First, these regions are dynamic and changing rapidly and the marketing strategies relevant to local companies are, in such an environment, very much region-specific (Chao et al., 2004). Papers on international marketing issues published in high-quality journals based on data in developed countries might be irrelevant to local companies and researchers. Thus, these journals are not heavily read by local researchers and there is no incentive to publish in them if the work will not be recognized by their local community. As with multinational companies which have just recently discovered that in order to succeed in these regions they need to adapt their international marketing strategy, leading international marketing journals have just started to recognize research in these regions as relevant to international theory development (primarily through special issues). Second, international scholars from developed countries have shown little interest in performing research in both regions. Most research to date has been undertaken by local scholars who were educated either in the US, UK or other developed countries. It is time for a change among leading international marketing journals and international scholars towards recognizing the importance and uniqueness of these regions.

\section{1. $\quad$ Future research directions}

We provide several examples of possible future research in the ME and Africa based on the recognition that these regions require different research approaches than those used in more developed regions of the world. Such differences would include the use of tweaked theories and new research methods, which would ultimately generate a different set of managerial implications and recommendations. We use the construct of market orientation to illustrate several benefits of examining a concept originating in developed countries in studies in the $\mathrm{ME}$ and Africa regions. 
A core research question that needs to be addressed in the ME and Africa involves the theoretical and practical meaning of market orientation. First, the original conceptualizations of market orientation (Kohli and Jaworski, 1990; Narver and Slater, 1990) were based on insights garnered from the US. Thus, Kohli and Jaworski (1990) conceptualized market orientation as composed of intelligence generation, intelligence dissemination, and responsiveness. In contrast, Narver and Slater (1990) viewed market orientation as composed of customer orientation, competitor orientation, and interfunctional coordination. However, would (and should) market orientation be conceptualized differently in the ME and Africa? Furthermore, what does market orientation mean for practicing managers in these regions and how is it manifested for firms in the ME and Africa? Ingenbleek et al.'s (2013) paper illustrates this point well. This study is anchored in field research in subsistence markets, with an application of market orientation in the context of Ethiopian pastoralists. The outstanding feature of this contribution is that the authors used innovative methods to test a standard market orientation model that would have been impossible to test using standard marketing research techniques and tools. Their approach was based on the argument that the characteristics of bottom of the pyramid markets challenge the generalizability of marketing theories and the applicability of widely used field research methods.

A second issue relates to the existence and possible strength of the impact of market orientation on different facets of organizational performance. Recently, Kumar et al. (2011) provided a compelling argument and empirical evidence to the claim that market orientation may have lost its role as a source of sustainable competitive advantage and may have become part of the cost of competing in general. We do not contend that the major tenet of this paper is misguided. However, we recognize that their argument might have been based on evidence from organizations in developed countries, rather than in the ME/Africa. Since both leading conceptualizations of market orientation were developed in the US, where the concept has 
enjoyed the most time to be disseminated and applied by practitioners, we argue that this finding will mostly not hold in the ME and Africa where market orientation research is not as developed. Notably, Shoham et al. (2005, pp. 448-9) conducted a meta-analysis on performance outcomes of market orientation. They summarized part of their findings in a way that bears on the topic of this paper:

American samples, as a whole, exhibited a weaker relationship between MO [market orientation] and performance than those drawn elsewhere. This result is intriguing since both major approaches to conceptualizing and measuring MO were developed in the USA. Our findings indicate that, while the MO-to-performance relationship is relatively robust and generalizes across nations, its impact depends on the country setting. MO may have its greatest effect in nations where high standards of consumer service and expectations are still evolving. In such countries, MO may allow firms to create competitive advantage by providing a higher level of service than their competitors.

To the extent that similar arguments can be made for other strategic concepts, such as green marketing-mix programs (see Leonidou et al., 2013), sound strategies could contribute more to organizational performance due to their novelty in the ME and Africa contexts compared to developed countries. Examples abound and include issues such as other business orientations (e.g. learning, innovative, and entrepreneurial orientations), as well as subsequent capabilities in these domains. These issues, along with green marketing-mix programs, require future research attention.

In sum, numerous research questions may require similar approaches to the one adopted by Ingenbleek et al. (2013). The importance of these future studies lies in enhanced 
possibilities to extend theory. For example, many studies in international marketing rely on conceptualizations and operationalizations of international performance developed by Zou et al. (1998) and Shoham (1996, 1998). However, such conceptualizations might be more fitting to firms in developed countries than to those in the ME and Africa. Speculatively, companies in the ME and Africa might be more interested in survival than in attaining strategic goals, a component of performance suggested by Zou et al. (1998) or in a change in export profits over five years, a component of performance advocated by Shoham $(1996,1998)$. If such speculations hold and survival is the overall goal, research is needed to identify new types of performance outcomes. Business survival as a goal also requires different tools of analysis, which are based on event analyses, rather than the regression/SEM approaches popular in the extant literature. Alternatively, the time since market orientation was introduced by firms might be used as a moderator of the market orientation-performance relationship. Less familiar relationships (non-linear) might be tested with the relationship being stronger for companies just introducing the concept when compared to more established companies that have used it for extended periods.

Finally and interestingly, future research should include cross-national studies, preferably including samples from the ME and African countries, which would be compared and contrasted in one of two ways. One approach would rely on the comparison to firms from developed countries; the second would use companies from other less developed regions. In both cases, the attempt will be to assess if "how things work" in the ME or Africa is the same as "how things work" in western countries (i.e. the first approach) or in other less developed regions (i.e. the second approach). 


\section{References}

Abdul-Muhmin, A.G. (2005), "Instrumental and interpersonal determinants of relationship satisfaction and commitment in industrial markets", Journal of Business Research, Vol. 58, pp. 619-28.

Adesida, O. and Karuri-Sebina, G. (2011), "Is Africa the land of the future? It is not a given!", Foresight, Vol. 13 No. 3, pp. 3-6.

Ahmed, S.A. and d'Astous, A. (2008), “Antecedents, moderators and dimensions of countryof-origin evaluations”, International Marketing Review, Vol. 25 No. 1, pp. 75-106.

Akbar, Y.H. and Samii, M. (2005), "Emerging markets and international business: a research agenda", Thunderbird International Business Review, Vol. 47 No. 4, pp. 389-96.

Al-Khatib, J., Stanton, A.D. and Rawwas, M.Y.A. (2005), "Ethical segmentation of consumers in developing countries: a comparative analysis", International Marketing Review, Vol. 22 No. 2, pp. 225-46.

Al-Olayan, F.S. and Karande, K. (2000), “A content analysis of magazine advertisements from the United States and the Arab world", Journal of Advertising, Vol. 29 No. 3, pp. 69-82.

Babakus, E., Yavas, U., Karatepe, O.M. and Avci, T. (2003), "The effect of management commitment to service quality on employees' affective and performance outcomes", Journal of the Academy of Marketing Science, Vol. 31 No. 3, pp. 272-86.

Batislam, E.P., Denizel, M. and Filiztekin, A. (2007), "Empirical validation and comparison of models for customer base analysis", International Journal of Research in Marketing, Vol. 24 No. 3, pp. 201-9.

Bilgin, P. (2006), "What future for Middle Eastern studies?", Futures, Vol. 38, pp. 575-85.

Brand, L.A. (2007), "Middle East studies and academic freedom: challenges at home and abroad”, International Studies Perspectives, Vol. 8 No. 4, pp. 384-95.

Briner, R.B., Denyer, D. and Rousseau, D.M. (2009), "Evidence-based management: concept cleanup time?", Academy of Management Perspectives, Vol. 23 No. 4, pp. 19-32.

Burgess, S.M. and Steenkamp, J.E.M. (2006), "Marketing renaissance: how research in emerging markets advances marketing science and practice", International Journal of Research in Marketing, Vol. 23 No. 4, pp. 337-56.

Chao, P., Samiee, S. and Yip, L.S.C. (2004), "Guest editorial - international marketing in the Asia-Pacific region”, International Marketing Review, Vol. 21 No. 3, pp. 243-46.

Cohen, R.J. (1999), "What qualitative research can be", Psychology \& Marketing, Vol. 16 No. 4, pp. 351-69.

Craig, C.S. and Douglas, S. (2005), International Marketing Research, John Wiley, Chichester. 
Demirbag, M., Apaydin, M. and Tatoglu, E. (2011), "Survival of Japanese subsidiaries in the Middle East and North Africa", Journal of World Business, Vol. 46 No. 4, pp. 411-25.

DuBois, F.L. and Reeb, D. (2000), "Ranking the international business journals", Journal of International Business Studies, Vol. 31 No. 4, pp. 689-704.

Erdem, T., Swait, J. and Valenzuela, A. (2006), "Brands as signals: a cross-country validation study", Journal of Marketing, Vol. 70 No. 1, pp. 34-49.

Essoussi, L.H. and Merunka, D. (2007), “Consumers' product evaluations in emerging markets: does country of design, country of manufacture, or brand image matter?", International Marketing Review, Vol. 24 No. 4, pp. 409-26.

Fahmy, E.I. and Rifaat, N.M. (2010), "Middle East information literacy awareness and indigenous Arabic content challenges", International Information and Library Review, Vol. 42 No. 2, pp. 111-23.

Fastoso, F. and Whitelock, J. (2010), "Regionalization vs. globalization in advertising research: insights from five decades of academic study", Journal of International Management, Vol. 16 No. 1, pp. 32-42.

Fastoso, F. and Whitelock, J. (2011), "Why is so little marketing research on Latin America published in high quality journals and what can we do about it? Lessons from a Delphi study of authors who have succeeded," International Marketing Review, Vol. 28 No. 4, pp. 435-49.

Gilmore, A., O’Donnell, A., Carson, D. and Cummins, D. (2003), 'Factors influencing foreign direct investment and international joint ventures: a comparative study of Northern Ireland and Bahrain”, International Marketing Review, Vol. 20 No. 2, pp. 195215.

Godley, A. and Shechter, R. (2008), "Editors' introduction: Business history and the Middle East: local contexts, multinational responses-A special section of Enterprise \& Society", Enterprise \& Society, Vol. 9 No. 4, pp. 631-36.

Grier, S.A. and Deshpandé, R. (2001), "Social dimensions of consumer distinctiveness: the influence of social status on group identity and advertising persuasion”, Journal of Marketing Research, Vol. 38 No. 2, pp. 216-24.

Griffith D.A., Cavusgil, S.T. and Xu, S. (2008), "Emerging themes in international business research”, Journal of International Business Studies, Vol. 39 No. 7, pp. 1220-35.

Henthorne, T.L., LaTour, M.S. and Loraas, T. (1998), "Publication productivity in three leading U.S. advertising journals: 1989 through 1996”, Journal of Advertising, Vol. 27 No. 2, pp. 53-63.

Heyneman, S.P. (1997), "The quality of education in the Middle East and North Africa (MENA)", International Journal of Educational Development, Vol. 17 No. 4, pp. 44966. 
Hirschman, E.C. (1986), "Humanistic inquiry in marketing research: philosophy, method, and criteria", Journal of Marketing Research, Vol. 23 No. 3, pp. 237-49.

Hitt, M.A., Li, H. and Worthington, W.J. (2005), "Emerging markets as learning laboratories: learning behaviours of local firms and foreign entrants in different institutional contexts", Management and Organization Review, Vol. 1 No. 3, pp. 353-80.

Hult, G.T.M., Reimann, M. and Schilke, O. (2009), "Worldwide faculty perceptions of marketing journals: rankings, trends, comparisons, and segmentations", Global Business Review, Vol. 3 No. 3, pp. 1-23.

Ingenbleek, P., Tessema, W.K. and van Trijp, H. (2013), "Conducting field research in subsistence markets, with an application to market orientation in the context of Ethiopian pastoralists", International Journal of Research in Marketing, Vol. 30 No. 1, pp. 83-97.

Kalliny, M. (2010), "Are they really that different from us: a comparison of Arab and American newspaper advertising", Journal of Current Issues and Research in Advertising, Vol. 32 No. 1, pp. 95-108.

Kamoche, K. (2011), "Contemporary developments in the management of human resources in Africa", Journal of World Business, Vol. 46 No. 1, pp. 1- 4.

Kearney, C. (2012), "Emerging markets research: trends, issues and future directions", Emerging Markets Review, Vol. 13 No. 2, pp. 159-83.

Kemp, L.J. (2010), “Access to fieldwork: 'strange' work in a Middle East setting”, Education, Business and Society: Contemporary Middle Eastern Issues, Vol. 3 No. 4, pp. 289-298.

Kohli, A. K., and Jaworski, B. J. (1990), "Market orientation: the construct, research propositions, and managerial implications", Journal of Marketing, Vol. 54 No. 2, pp. 118.

Kumar, V., Jones, E., Venkatesan, R. and Leone, R.P. (2011), "Is market orientation a source of sustainable competitive advantage or simply the cost of competing?", Journal of Marketing, Vol. 75 No. 1, pp. 16-30.

Lahiri, S. (2011), "Brazil-focused publications in leading business journals", European Business Review, Vol. 23 No. 1, pp. 23-44.

Lee, R., Klobas, J., Tezinde, T. and Murphy, J. (2010), “The underlying social identities of a nation's brand”, International Marketing Review, Vol. 27 No. 4, pp. 450-65.

Lee-Kelley, L., Gilbert, D. and Al-Shehabi, N.F. (2004), "Virtual exhibitions: an exploratory study of Middle East exhibitors' dispositions”, International Marketing Review, Vol. 21 No. 6, pp. 634-44.

Leonidou, L.C., Barnes, B.R., Spyropoulou, S. and Katsikeas, C.S. (2010), “Assessing the contribution of leading mainstream marketing journals to the international marketing discipline”, International Marketing Review, Vol. 27 No. 5, pp. 491-518. 
Leonidou, C.N., Katsikeas, C.S. and Morgan, N.A. (2013), "Greening" the marketing mix: do firms do it and does it pay off?, Journal of the Academy of Marketing Science, Vol. 41 No. 2, 151-170.

Luqmani, M., Quraeshi, Z. and Yavas, U. (1989), “Advertising in Saudi Arabia: content and regulation”, International Marketing Review, Vol. 6 No. 3, pp. 59-72.

Melewar, T.C., Turnbull, S. and Balabanis, G. (2000), "International advertising strategies of multinational enterprises in the Middle East", International Journal of Advertising, Vol. 19, pp. 529-47.

Mellahi, K., Demirbag, M. and Riddle, L. (2011), "Multinationals in the Middle East: challenges and opportunities", Journal of World Business, Vol. 46 No. 4, pp. 406-10.

Narver, J. C. and Slater, S. F. (1990), "The effect of a market orientation on business profitability”. The Journal of Marketing, Vol. 54 No. 4, pp. 20-35.

North, D.C. (1990), Institutions, Institutional Change and Economic Performance, Cambridge University Press.

Okazaki, S. and Mueller, B. (2007), "Cross-cultural advertising research: where we have been and where we need to go", International Marketing Review, Vol. 24 No. 5, pp. 499518.

Onyancha, O.B. (2011), "Research collaborations between South Africa and other countries, 1986-2005: an informetric analysis", African Journal of Library, Archives \& Information Science, Vol. 21 No. 2, pp. 99-112.

Oyedele, A., Minor, M.S. and Ghanem, S. (2009), "Signals of global advertising appeals in emerging markets”, International Marketing Review, Vol. 26 No. 4/5, pp. 521-41.

Pillania, R.K. (2009), "Multinationals and emerging markets", Business Strategy Series, Vol. 10 No. 2, pp. 100-3.

Razzouk, N. and Al-Khatib, J. (1993), "The nature of television advertising in Saudi Arabia: content analysis and marketing implications", Journal of International Consumer Marketing, Vol. 6 No. 2, pp. 65-90.

Royne Stafford, M. (2005), "International services advertising (ISA): defining the domain and reviewing the literature", Journal of Advertising, Vol. 34 No. 1, pp. 65-86.

Ruscoe, J. (2008), "A new role for research in achieving prosperity in the Middle East", Education, Business and Society: Contemporary Middle Eastern Issues, Vol. 1 No. 1, pp. 6-11.

Sakarya, S., Eckman, M. and Hyllegard, K.H. (2007), "Market selection for international expansion: assessing opportunities in emerging markets", International Marketing Review, Vol. 24 No. 2, pp. 208-38.

Sawyerr, A. (2004), "African universities and the challenge of research capacity development", Journal of Higher Education in Africa, Vol. 2 No. 1, pp. 211-40. 
Schuh, A. (2010), "How research on marketing in Central and Eastern Europe can advance international marketing theory/Kako istrazivanja o marketingu u srednjoj i istocnoj Europi mogu unaprijediti teoriju medunarodnog marketinga”, Trziste = Market, Vol. 22 No. 2, pp. 255-268.

Shoham, A. (1996), "Marketing-mix standardization: determinants of export performance", Journal of Global Marketing, Vol. 10 No. 2, pp. 53-73.

Shoham, A. (1998), "Export performance: a conceptualization and empirical assessment", Journal of International Marketing, Vol. 6 No. 3, pp. 59-81.

Shoham, A., Rose, G. M. and Kropp, F. (2005), "Market orientation and performance: a meta-analysis", Marketing Intelligence \& Planning, Vol. 23 No. 5, pp. 435-54.

Souiden, N. (2002), "Segmenting the Arab markets on the basis of marketing stimuli", International Marketing Review, Vol. 19 No. 6, pp. 611-36.

Speck, S.K. and Roy, A. (2008), "The interrelationships between television viewing, values and perceived well-being: a global perspective", Journal of International Business Studies, Vol. 39 No. 7, pp. 1197-219.

Steenkamp, J.E.M. and Burgess, S.M. (2002), “Optimum stimulation level and exploratory consumer behavior in an emerging consumer market", International Journal of Research in Marketing, Vol. 19 No. 2, pp. 131-50.

Story, V. M., Boso, N. and Cadogan, J. W. (2014), "The Form of Relationship between FirmLevel Product Innovativeness and New Product Performance in Developed and Emerging Markets", Journal of Product Innovation Management.

Tesfom, G., Lutz, C. and Ghauri, P. (2004), "Comparing export marketing channels: developed versus developing countries”, International Marketing Review, Vol. 21 No. 4, pp. 409-22.

Touzani, M. and Moussa, S. (2010), "Ranking marketing journals using the search engine Google Scholar”, Marketing Education Review, Vol. 20 No. 3, pp. 229-47.

United Nations (2012), "Middle-East and North Africa list of countries", available at: http://unstats.un.org/unsd/methods/m49/m49regin.htm (accessed 21 September 2012).

Wallendorf, M. and Belk, R.W. (1989), "Assessing trustworthiness in naturalistic consumer research”, in Hirschman, E.C. (Ed.), Interpretive Consumer Research, Association for Consumer Research, Provo, UT, pp. 69-84.

Walters, P.G.P. and Samiee, S. (2003), "Marketing strategy in emerging markets: the case of China", Journal of International Marketing, Vol. 11 No. 1, pp. 97-106.

World Bank (2011), "Middle-East and North Africa list of countries", available at: http://www.worldbank.org/en/region/mena (accessed 21 September 2012). 
Zou, S., Taylor, C.R. and Osland, G.E. (1998), "The EXPERF scale: a cross-national generalized export performance measure", Journal of International Marketing, Vol. 6 No. 3, pp. 37-58. 
Table I. List of marketing, international business, and advertising journals under research

\begin{tabular}{|c|c|}
\hline $\begin{array}{l}\text { Marketing (Hult et al., 2009; } \\
\text { Touzani and Moussa, 2010; } \\
\text { Leonidou et al., 2010) }\end{array}$ & $\begin{array}{l}\text { International Journal of Research in Marketing * } \\
\text { Journal of the Academy of Marketing Science * } \\
\text { Journal of Marketing * } \\
\text { Journal of Business Research* } \\
\text { Journal of Consumer Research * } \\
\text { Journal of Marketing Research * } \\
\text { Journal of Retailing * } \\
\text { Marketing Science * } \\
\text { Industrial Marketing Management } \\
\text { Journal of Product Innovation Management } \\
\text { European Journal of Marketing } \\
\text { Journal of Consumer Psychology } \\
\text { Journal of Service Research }\end{array}$ \\
\hline $\begin{array}{l}\text { International business (DuBois and } \\
\text { Reeb, 2000) }\end{array}$ & $\begin{array}{l}\text { International Marketing Review * } \\
\text { Journal of International Business Studies * } \\
\text { Journal of World Business * } \\
\text { Journal of International Marketing * } \\
\text { Management International Review * } \\
\text { International Business Review }\end{array}$ \\
\hline $\begin{array}{l}\text { Advertising (Henthorne et al., } \\
\text { 1998; Royne Stafford, 2005) }\end{array}$ & $\begin{array}{l}\text { Journal of Advertising * } \\
\text { Journal of Advertising Research * } \\
\text { Journal of Current Issues and Research in } \\
\text { Advertising * } \\
\text { International Journal of Advertising * }\end{array}$ \\
\hline
\end{tabular}

* based on Fastoso and Whitelock (2011) classification. 
Table II. Frequency of challenges mentioned in conducting and publishing research in the ME

\begin{tabular}{|c|c|}
\hline Challenges & Frequency \\
\hline Validity and reliability of the data & 9 \\
\hline Language barriers & 7 \\
\hline Data collection & 7 \\
\hline Availability of a network of researchers (competent collaborators) & 7 \\
\hline Top journals do not publish single non-US country study & 7 \\
\hline Access to data/suitable participants & 6 \\
\hline Fighting preconceptions about the region (ME research as low quality) & 6 \\
\hline Hard to extend results to other markets & 6 \\
\hline Editors' low interest about the area & 6 \\
\hline Reviewers' low interest about the area & 6 \\
\hline Quality of the data & 5 \\
\hline Hard to become member of clubs in the West & 5 \\
\hline Lack of (or no) reliable secondary data & 4 \\
\hline Low respondent participation & 4 \\
\hline Majority of research is a replication of existing theories & 4 \\
\hline Weak link between universities and companies & 3 \\
\hline Differences between cultures in the ME region & 3 \\
\hline Reviewers' limited knowledge about the area & 3 \\
\hline General lack of trust (high suspicion in the surveys) & 2 \\
\hline Difficult to obtain permission from governments to conduct research & 2 \\
\hline Difficulties in approaching women as respondents & 2 \\
\hline Mail system is not developed & 2 \\
\hline Low research support from institutions & 2 \\
\hline Limited number of studies in the region to draw from & 2 \\
\hline Editors' limited knowledge about the area & 2 \\
\hline No list of firms to determine population & 1 \\
\hline Lack of institutionalization (spotting the right person in a company) & 1 \\
\hline Door-to-door data collection is prohibited in some countries & 1 \\
\hline Limited resources (budgets, post-docs) & 1 \\
\hline Overload and other non-research obligations & 1 \\
\hline No funding of research by companies & 1 \\
\hline Difficult to obtain a random sample & 1 \\
\hline A need for personal contact & 1 \\
\hline Instability and violence in some countries & 1 \\
\hline Lack of prior knowledge and education & 1 \\
\hline Low priority of research for local academics & 1 \\
\hline Low possibility to compare data to population & 1 \\
\hline Novel approach to face problems in ME countries & 1 \\
\hline Due to distinct religion/culture, often only a case study method is used & 1 \\
\hline Limited exposure to other researchers' work & 1 \\
\hline
\end{tabular}


Table III. Frequency of challenges mentioned in conducting and publishing research in Africa

\begin{tabular}{|c|c|}
\hline Challenges & Frequency \\
\hline Access to data/suitable participants & 11 \\
\hline Data collection (qualitative, time consuming, safety issues) & 10 \\
\hline $\begin{array}{l}\text { Diversity of the region (economic, political and cultural, e.g. multiple } \\
\text { languages, familiarity with the context) }\end{array}$ & 10 \\
\hline $\begin{array}{l}\text { Infrastructure for research support does not exist (e.g. internet access, } \\
\text { difficult communication) }\end{array}$ & 8 \\
\hline Editors' low interest about the area & 7 \\
\hline Reviewers' low interest about the area & 6 \\
\hline Literacy of respondents & 5 \\
\hline $\begin{array}{l}\text { Business environment (e.g. difficult to obtain permission from firms } \\
\text { to conduct research, less conventional business profile) }\end{array}$ & 5 \\
\hline Reviewers' limited knowledge about the area & 5 \\
\hline Costs of gathering data & 4 \\
\hline Hard to extend results to other markets & 4 \\
\hline Teaching and consultancy demands & 3 \\
\hline The majority of academics do not hold a PhD & 3 \\
\hline Quality of the data & 3 \\
\hline Perception of research in Africa as of low quality & 3 \\
\hline High levels of corruption, crime, and poor governance & 2 \\
\hline Low priority of research for local academics & 2 \\
\hline Knowledge of collaborators & 2 \\
\hline $\begin{array}{l}\text { Limited publication outlets (only few highly ranked journals accept } \\
\text { qualitative research) }\end{array}$ & 2 \\
\hline Top journals do not publish single country study & 2 \\
\hline Theory applicable to African business context & 2 \\
\hline Editors' limited knowledge about the area & 2 \\
\hline Low respondent participation (consider it a waste of time) & 1 \\
\hline No incentives for publications at international level & 1 \\
\hline $\begin{array}{l}\text { Incentives for research do not distinguish between international/local } \\
\text { journals despite international publication expectations }\end{array}$ & 1 \\
\hline $\begin{array}{l}\text { Methodological constraint (most of the scales do not work with non- } \\
\text { student population) }\end{array}$ & 1 \\
\hline Validity and reliability of the data & 1 \\
\hline Lack of research partnerships & 1 \\
\hline
\end{tabular}


Table IV. Insights from this research and solutions regarding conducting and publishing research in these regions

\begin{tabular}{|c|c|}
\hline Insights & Solutions \\
\hline \multicolumn{2}{|c|}{ (1) CONDUCTING RESEARCH } \\
\hline Tight budgets & $\begin{array}{l}\text { Establish specific budgets allocated to research at the } \\
\text { governmental level. Part of this budget would be } \\
\text { allocated to PhD scholarships in high-ranked international } \\
\text { universities. The expectation would be that these newly } \\
\text { formed academics would return to the home country to } \\
\text { strengthen the research culture in local universities. } \\
\text { Alternatively, a one-year PhD study abroad program with } \\
\text { the aim of PhD candidates conducting research at a } \\
\text { worldwide-recognized university to enhance their training } \\
\text { and foster international research collaborations would be } \\
\text { sponsored by the government. Additionally, current } \\
\text { academics would be encouraged to establish affiliations } \\
\text { or institutional links with worldwide-recognized } \\
\text { universities abroad, which would foster exchange visiting } \\
\text { scholars' programs, international research collaboration } \\
\text { (also to disseminate their ideas) and joint training } \\
\text { programs. } \\
\text { Researchers should be encouraged to apply for local and } \\
\text { international grants. Notably, local grants are available } \\
\text { and are used for local projects, which, for the most part, } \\
\text { do not lead to high-quality publications. Thus, we } \\
\text { recommend that tenure and promotion decisions, in } \\
\text { particular of researchers, who were trained } \\
\text { internationally, should be based partially on successful } \\
\text { application for international grants. }\end{array}$ \\
\hline $\begin{array}{l}\text { Constraints in getting data from } \\
\text { institutions }\end{array}$ & $\begin{array}{l}\text { Establish researchers' cooperation with local and } \\
\text { international companies, in particular big multinational } \\
\text { companies, at all levels (e.g. academic expert talks, } \\
\text { student projects, consultancy projects, etc.) with the aim } \\
\text { of creating awareness among managers about the } \\
\text { importance of research. This would be followed by } \\
\text { researchers training managers of local and international } \\
\text { companies on how to conduct research. Due to the } \\
\text { hierarchical nature of the societies in these regions, } \\
\text { managers would subsequently pass on the knowledge and } \\
\text { instructions to their employees regarding the } \\
\text { implementation of data collection. } \\
\text { Hence, survey response rates could increase if these } \\
\text { company managers sponsor the distribution of the } \\
\text { academic survey by, for instance, offering an incentive } \\
\text { and explaining its relevance to the company stakeholders } \\
\text { (e.g. employees, suppliers, clients, etc.) }\end{array}$ \\
\hline
\end{tabular}




\begin{tabular}{|c|c|}
\hline & $\begin{array}{l}\text { Train researchers on developing proposals for } \\
\text { cooperation with companies, which are attractive from } \\
\text { the company's perspective, so that primary data and } \\
\text { secondary company data could be collected. Researchers } \\
\text { should also try to combine these data with secondary data } \\
\text { sources from internationally recognized NGOs, the World } \\
\text { Bank, national/regional statistics offices, etc. } \\
\text { Local universities should focus on developing better } \\
\text { archival databases to ultimately provide good access to } \\
\text { up-to-date data for their scholars. }\end{array}$ \\
\hline $\begin{array}{l}\text { Low priority of research for } \\
\text { local academics }\end{array}$ & $\begin{array}{l}\text { Universities should offer higher amounts of research } \\
\text { funds to those who publish in internationally recognized } \\
\text { journals (vs. those who publish in local journals). } \\
\text { Creating this culture of competition at the international } \\
\text { rather than the local level would increase the incentives of } \\
\text { academics to publish in high-quality international } \\
\text { journals. } \\
\text { Two tenure tracks should be established: teaching and } \\
\text { research. The primary focus for the teaching track should } \\
\text { be lecturing, while workload for the research track should } \\
\text { account for research time and thus teaching would be } \\
\text { reduced. } \\
\text { Success at publishing in international journals should be } \\
\text { linked to rewards and ultimately the promotion of } \\
\text { scholars. }\end{array}$ \\
\hline \multicolumn{2}{|c|}{ (2) PUBLISHING RESEARCH } \\
\hline $\begin{array}{l}\text { Editors' and reviewers' low } \\
\text { interest in the ME and Africa } \\
\text { regions }\end{array}$ & $\begin{array}{l}\text { Conference chairs are recommended to invite editors of } \\
\text { high-quality international journals in the marketing field } \\
\text { to the major conferences in these regions in order to } \\
\text { increase not only editors' knowledge of these regions but } \\
\text { also editors' role in promoting the development of quality } \\
\text { research by delivering special sessions about publishing } \\
\text { in high-quality international journals. Once editors are } \\
\text { more knowledgeable about a region, initiatives such as } \\
\text { special issues and specific editorials on these regions } \\
\text { should also promote reviewers' interest. Other journals } \\
\text { should follow the example set by the Journal of World } \\
\text { Business, by having special issues on these regions in } \\
\text { order to increase the interest among scholars and } \\
\text { ultimately introduce local researchers to an international } \\
\text { audience. } \\
\text { Universities and business schools in particular should } \\
\text { focus on creating a culture of publishing at the } \\
\text { international rather than regional/country level so that }\end{array}$ \\
\hline
\end{tabular}




\begin{tabular}{|c|c|}
\hline & $\begin{array}{l}\text { submissions from these regions would increase. } \\
\text { Local researchers should aim to complement their studies } \\
\text { with samples from western countries, which allows for } \\
\text { comparisons valued by both editors and reviewers of } \\
\text { high-quality international journals. } \\
\text { 'Superstar' researchers in the field of marketing would } \\
\text { increase the credibility of these regions as a potential } \\
\text { research context by publishing in high-quality } \\
\text { international journals using data from these regions. }\end{array}$ \\
\hline Data, analysis, and text quality & $\begin{array}{l}\text { Local researchers should find an international } \\
\text { collaborator with experience in publishing in high-quality } \\
\text { international journals from whom they could not only } \\
\text { learn "the rules of the game" but also have access to more } \\
\text { recent literature, which is difficult to access in some } \\
\text { countries in Africa. In turn, the benefit for these } \\
\text { international collaborators would be the possibility of } \\
\text { using local knowledge to collect data (e.g. language) to } \\
\text { conduct cross-cultural studies. In an ideal world, local } \\
\text { researchers would complement their study with a western } \\
\text { sample, which would enable comparisons that are valued } \\
\text { especially by high-quality international journals. } \\
\text { As knowledge of local researchers was often stressed as } \\
\text { an issue, local universities are advised to aim to create } \\
\text { PhD programs with an international standard, namely by } \\
\text { inviting internationally recognized scholars to lecture and } \\
\text { be PhD committee members; thereby sharing their } \\
\text { knowledge with local researchers and subsequently } \\
\text { developing international research cooperation. For } \\
\text { instance, an important step in the development of a PhD } \\
\text { candidate would be doctoral training by writing the front } \\
\text { end of the paper in collaboration with an internationally } \\
\text { recognized scholar. Furthermore, as discussed previously, } \\
\text { visiting positions of local researchers to overseas } \\
\text { universities where research standards are higher (e.g. the } \\
\text { USA, UK, etc.) should be promoted to understand the } \\
\text { techniques needed to get in to high-quality international } \\
\text { journals. } \\
\text { If local researchers aim to publish a paper in high-quality } \\
\text { international marketing journals, the topic should be } \\
\text { relevant and the study should be rigorous. When } \\
\text { designing a study, we suggest that local researchers } \\
\text { develop a strong conceptual part of the paper first, before } \\
\text { starting data collection. In this process, it is important to } \\
\text { understand how the relationships in the model are } \\
\text { supported conceptually and the study's contribution to }\end{array}$ \\
\hline
\end{tabular}




\begin{tabular}{|l|l|}
\hline $\begin{array}{l}\text { theory and practice before data collection takes place. } \\
\text { During data collection, multiple pre-tests should be } \\
\text { encouraged. At all stages of the paper development, the } \\
\text { researcher(s) should have in mind who is the target } \\
\text { audience when positioning the paper. Finally, seeking } \\
\text { practitioners' comments on data results should be } \\
\text { encouraged to guarantee the study's practical relevance } \\
\text { and generate managerial implications. }\end{array}$ \\
$\begin{array}{l}\text { With regard to text quality, one of the main reasons for } \\
\text { desk rejections was English proficiency. Hiring a } \\
\text { professional copy editor to read the manuscript before } \\
\text { submission to the journal is of extreme importance. }\end{array}$ \\
\hline
\end{tabular}


Figure 1. Challenges in conducting and publishing research in Africa

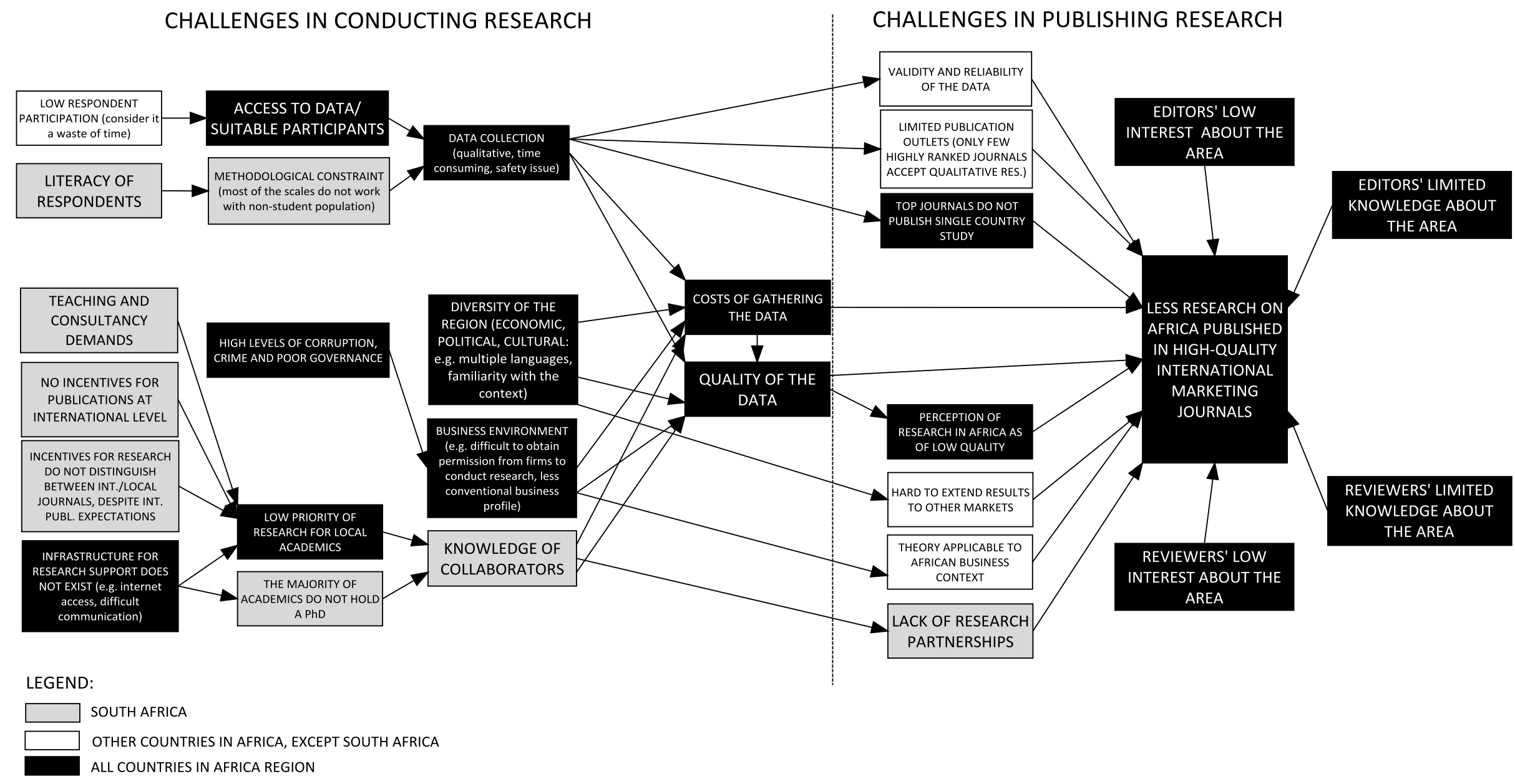


Figure 2. Challenges in conducting and publishing research in the ME

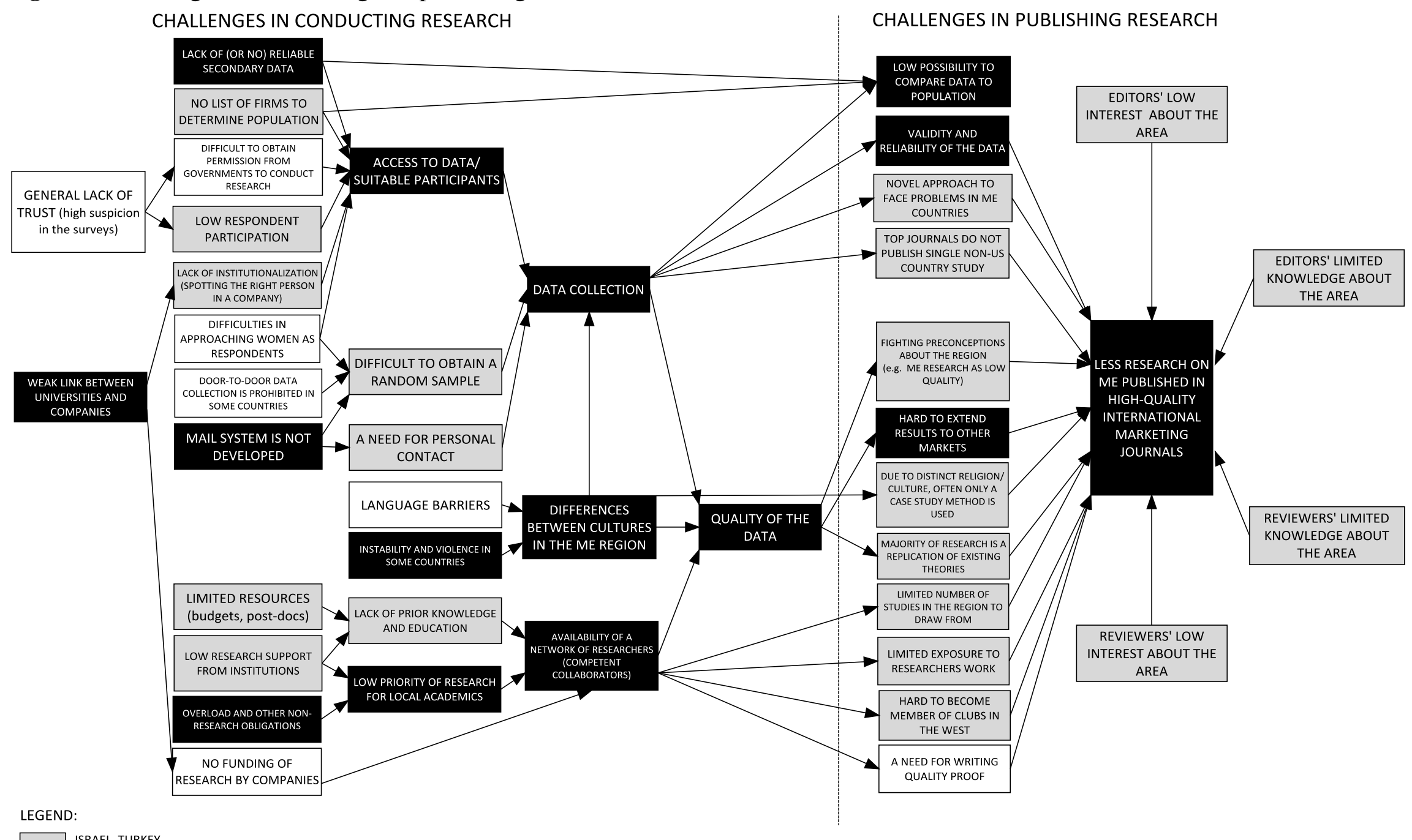

LEGEND:

OTHER COUNTRIES IN MIDDLE EAST, EXCEPT ISRAEL AND TURKEY

ALL COUNTRIES IN MIDDLE EAST REGION 